\title{
Pengelompokan Daerah Rawan Demam Berdarah Dengue di Provinsi DKI Jakarta
}

\author{
Afifatul Ilma Widyatami, Dwi Ari Suryawan \\ Politeknik Statistika STIS, Jakarta, Indonesia \\ Jalan Otto Iskandardinata No.64C Jakarta Timur \\ Korespondensi E-mail: 211709499@stis.ac.id
}

Submitted: 29 Maret 2021, Revised: 27 Mei 2021, Accepted: 12 Juni 2021

\begin{abstract}
Indonesia is the country with the highest cases of dengue fever in Southeast Asia, according to The World Health Organization (WHO) from 1968 to 2009. DKI Jakarta with high population density and flood intensity being cautioned for being aware of cases of dengue fever, because it may make growth in dengue mosquitoes spreading. Data show that almost every year DKI Jakarta is in the top 10 provinces with the highest cases of dengue fever. By using the clustering method, it is possible to make groups of data with similar characteristics into specific classes. Data used is secondary data from 2016 which is collected from the website bttps:/ / data.jakarta.go.id/. The result from clustering can be used to decide which zone needs special treatment based on numbers of dengue fever cases, prone to flood, areas wide, total population, temporary landfills, and green space numbers variables. From the analysis, we can conclude that DKI Jakarta has 19 sub-districts with bigh risk, 10 sub-districts with medium risk, and 15 subdistricts with low risk.
\end{abstract}

Keyword: dengue fever, cluster analysis, DKI Jakarta

\begin{abstract}
Abstrak
Indonesia merupakan negara dengan kasus demam berdarah dengue tertinggi di Asia Tenggara sejak tahun 1968 hingga tahun 2009 berdasarkan data World Health Organization (WHO). DKI Jakarta dengan kepadatan penduduknya yang tinggi dan intensitas banjir yang cukup tinggi menjadi perhatian agar dapat waspada terhadap kasus demam berdarah dengue, dikarenakan dapat memicu perkembangan nyamuk penyebab demam berdarah dengue. Data profil kesehatan Republik Indonesia menunjukan bahwa hampir setiap tahunnya provinsi DKI Jakarta memasuki 10 besar provinsi di Indonesia dengan kasus demam berdarah dengue terbanyak. Dengan menggunakan metode klaster, dapat dilakukan pengelompokan data dengan karakteristik yang memiliki kemiripan menjadi kelas-kelas tertentu. Data yang digunakan merupakan data sekunder pada tahun 2016 yang dikumpulkan melalui website https://data.jakarta.go.id/. Hasil dari analisis klaster dapat digunakan untuk menentukan daerah mana yang masuk ke dalam kategori yang perlu penanganan khusus berdasarkan variabel jumlah penderita demam berdarah dengue, jumlah rw rawan banjir, luas wilayah, jumlah penduduk, tempat pembuangan sementara dan jumlah ruang terbuka hijau. Dari analisis data yang dilakukan, dapat disimpulkan bahwa di DKI Jakarta terdapat kecamatan dengan tingkat kerawanan tinggi sebanyak 19 kecamatan, 10 kecamatan dengan tingkat kerawanan sedang dan 15 kecamatan dengan tingkat kerawanan rendah.
\end{abstract}

Kata Kunci: demam berdarah, analisis klaster, DKI Jakarta

\section{Pendahuluan}

Demam Berdarah Dengue (DBD) merupakan penyakit demam akut disebabkan oleh virus yang ditularkan oleh nyamuk. Nyamuk tersebut berasal dari nyamuk Aedes yang tersebar luas di daerah tropis dan subtropis di seluruh dunia (1). Penyebab timbulnya penyakit Demam Berdarah Dengue adalah empat virus dengue yang kemudian ditularkan melalui nyamuk Aedes Aegypti dan Aedes Albopictus. Nyamuk ini sebagian besar berada di daerah tropis dan subtropis yaitu antara Indonesia sampai bagian utara Australia (2)

Indonesia adalah salah satu negara dengan kasus DBD tertinggi di Asia Tenggara dengan Angka Kejadian/Incidence Rate (IR) DBD cenderung meningkat dari tahun ke tahun. Berdasarkan data IR DBD per provinsi milik Kementerian Kesehatan, pada tahun 2016, tiga provinsi dengan angka kesakitan DBD tertinggi adalah Bali, Kalimantan Timur, dan DKI Jakarta. Jumlah kasus kematian akibat DBD di seluruh 
Indonesia pada tahun 2016 mencapai 1585 kasus dengan kasus kematian tertinggi terdapat pada provinsi Jawa Timur.

Kasus DBD di DKI Jakarta dari tahun ke tahun fluktuatif, namun mengalami lonjakan yang besar di tahun 2015 ke 2016. Berdasarkan data pada profil kesehatan DKI Jakarta, jumlah kasus DBD yang tercatat tahun 2015 sebanyak 4194 kasus dan di tahun 2016 meningkat menjadi 22697 kasus. Lonjakan kasus ini merupakan yang tertinggi selama 5 tahun terakhir di DKI Jakarta. Untuk persebaran kasus DBD di Provinsi DKI Jakarta tahun 2015, wilayah dengan persebaran kasus DBD tertinggi berada di Jakarta Barat. Kemudian, pada tahun 2016 persebaran kasus DBD tertinggi di DKI Jakarta ada di kawasan Jakarta Timur. Hal ini menyebabkan pada tahun 2016, kota Jakarta Timur menjadi daerah endemik kasus DBD.

Daerah-daerah rawan DBD perlu diketahui agar masyarakat lebih berhati-hati jika sedang menempati suatu daerah, berniat menempati suatu daerah, atau bepergian ke daerah-daerah tersebut. Daerah Rawan DBD merupakan daerah yang memiliki risiko tinggi penularan penyakit DBD (3). Mengetahui daerah rawan DBD dapat memberikan sinyal peringatan kepada pemerintah, agar dapat lebih memberi perhatian khusus kepada daerah yang memiliki tingkat kerawanan tinggi.

Faktor-faktor penyebab endemik DBD di antaranya lingkungan, sosial, dan sarana kesehatan. Tindakan pencegahan perlu dilakukan ketika mengetahui daerah rawan DBD, seperti menjaga kebersihan lingkungan dan menghindari diri dari gigitan nyamuk, sangat bermanfaat dalam mengurangi risiko terjangkit DBD (3). Dengan mengetahui daerah yang rawan DBD dapat dilakukan tindak pencegahan atau upaya penurunan kasus pada daerah tersebut.

Berdasarkan penelitian A Ramadhani, P Widayani, BS Widartono(4) yang memetakan kerawanan DBD di Purwokerto Timur, salah satu variabel yang digunakan dalam penelitian adalah, jarak pemukiman dari sungai. Jarak pemukiman dari sungai menjadi salah satu variabel karena sebagian besar sungai yang melewati wilayah Kecamatan Purwokerto Timur merupakan sungai - sungai kecil yang memiliki banyak lubang dan batu - batu yang memiliki potensi untuk menjadi tempat genangan air ketika arus air tidak terlalu deras, dimana genangan - genangan air tersebut memiliki potensi untuk menjadi sarang nyamuk demam berdarah. Diketahui pula bahwa lokasi dataran banjir berasosiasi dengan aliran sungai dengan pola meandering (5). Selain itu, Banjir memiliki pengaruh tidak langsung terhadap DBD melalui perubahan iklim (6). Sehingga, pada penelitian ini, diputuskan menggunakan variabel wilayah rawan banjir level rukun warga (RW) yang tersebar di enam kabupaten/kota provinsi DKI Jakarta sebagai variabel pembangun cluster.

Faktor lain yang menjadi salah satu variabel dalam daerah rawan dbd adalah kepadatan penduduk (7). Kepadatan penduduk adalah luas wilayah $\left(\mathrm{km}^{2}\right)$ dibagi dengan jumlah penduduk per satuan unit. Kepadatan penduduk mempengaruhi proses penularan atau pemindahan penyakit dari satu orang ke orang lain. Tanpa adanya upaya-upaya pencegahan yang memadai, semakin padat penduduk maka menyebabkan semakin kondusif perkembangbiakan virus sehingga dapat mengakibatkan terjadinya peningkatan kasus (7),(8). Dengan kata lain, semakin kecil suatu wilayah atau semakin banyak jumlah penduduk di wilayah tersebut dapat mengakibatkan terjadinya peningkatan kasus. Sehingga diputuskan dalam penelitian ini untuk mengguanakan dua variabel pembentuk kepadatan penduduk, yaitu luas wilayah dan jumlah penduduk sebagai variabel proxy dalam pembentukan cluster, mengingat semakin banyak variabel yang digunakan maka akan semakin representative.

Pemanfaatan lahan untuk permukiman memiliki keterkaitan yang sangat erat terhadap DBD karena menyangkut habitat nyamuk Aedes spp. berkembangbiak sebagai vektor penular DBD. Permukiman yang padat, tingkat sanitasi yang rendah dan kesadaran masyarakat tentang kebersihan lingkungan yang kurang dapat meningkatkan risiko transmisi virus dengue oleh nyamuk Aedes spp (8). Karenanya, lahan yang sempit dan banyaknya jumlah penduduk yang tinggi dapat digunakan sebagai indikator atau parameter bahwa daerah tersebut mungkin rawan akan kasus DBD.

Dengan adanya penelitian ini, dapat menentukan daerah atau kecamatan mana saja yang perlu diberi perhatian khusus terhadap kasus DBD. Selain itu dengan adanya pengelompokan daerah rawan DBD, pemerintah provinsi dapat menentukan langkah-langkah apa saja yang dapat dilakukan untuk melawan kasus DBD di DKI Jakarta. Di sisi lain, dengan adanya penelitian ini dapat melihat gambaran umum kasus DBD di DKI Jakarta dan variabel-variabel pembangun cluster rawan DBD. 
Berdasarkan variabel-variabel yang telah ditinjau, dapat dibuat cluster tingkat kerawanan DBD di DKI Jakarta. Analisis cluster dapat dilakukan dengan cara pengelompokan kecamatan berdasarkan variabel-variabel yang digunakan. Hasil dari analisis cluster berupa pengkategorian kecamatan berdasarkan tingkat kerawanannya. Dari pengkategorian diharapkan masyarakat dan pemerintah dapat lebih waspada kepada daerah tersebut, sehingga dapat bertindak lebih cepat dan tepat dalam penyusunan kebijakan pemberantasan DBD di Provinsi DKI Jakarta.

Penelitian ini bertujuan untuk melihat gambaran variabel yang digunakan untuk mengelompokan daerah rawan DBD dari tiap kotamadya dan kabupaten di Provinsi DKI Jakarta, yang dilihat dari variabel jumlah penduduk, luas wilayah, jumlah RW rawan banjir, luas tempat pembuangan sampah, luas ruang terbuka hijau, dan jumlah kasus DBD. Kemudian, melakukan analisis deksriptif mendalam pada jumlah kasus DBD tiap kecamatan serta membuat peta persebarannya. Selanjutnya pengelompokan tiap kecamatan yang ada di Provinsi DKI Jakarta berdasarkan tingkatan kerawanan DBD menjadi tiga kategori menggunakan analisis cluster. Pada penelitian ini metode analisis cluster yang digunakan adalah Hierarchical Clustering dengan metode ragam minimum (Ward's Method). Hasilnya berupa pengkategorian kecamatan

\section{Metode Penelitian \\ Sumber Data}

Penelitian menggunakan data sekunder yang didapatkan dari hasil publikasi oleh pemprov DKI Jakarta melalui website data.jakarta.go.id. Data yang dikumpulkan adalah data cross sectional dengan data tahunan pada tahun 2016, dengan unit analisisnya adalah kecamatan yang ada di DKI Jakarta. Variabel yang digunakan untuk analisis adalah variabel jumlah penduduk, luas wilayah, jumlah rw rawan banjir, luas tempat pembuangan sampah, luas ruang terbuka hijau, dan jumlah kasus Demam Berdarah Dengue menurut kecamatan (Dikumpulkan pada bulan januari s.d Februari pada tahun 2016).

Tabel 1.

Variabel Yang Digunakan Sebagai Pembentuk Cluster

\begin{tabular}{|c|c|c|}
\hline Nama Variabel & Satuan Data & Sumber Data \\
\hline Jumlah Penduduk & Jiwa & Badan Pusat Statistik \\
\hline Luas Wilayah & Kilometer Persegi & $\begin{array}{l}\text { Dinas Kependudukan dan } \\
\text { Pencatatan Sipil }\end{array}$ \\
\hline Jumlah RW Rawan Banjir & Rukun Warga (RW) & $\begin{array}{l}\text { Badan Penanggulangan Bencana } \\
\text { Daerah (BPBD) }\end{array}$ \\
\hline $\begin{array}{l}\text { Luas Tempat Pembuangan } \\
\text { Sampah }\end{array}$ & Meter Persegi & Dinas Lingkungan Hidup \\
\hline Luas Ruang Terbuka Hijau & Meter Persegi & $\begin{array}{l}\text { Dinas Pertamanan dan } \\
\text { Pemakaman }\end{array}$ \\
\hline Jumlah Kasus DBD & Kasus & Dinas Kesehatan \\
\hline
\end{tabular}

Sumber: data.jakarta.go.id

\section{Metode Analisis}

Analisis Deskriptif

Analisis deskriptif ditujukan untuk melihat gambaran dari variabel yang digunakan secara umum. Analisis deskriptif yang dilakukan berupa pembuatan peta tematik, pembuatan tabel dan grafik. Tujuannya untuk melihat persebaran tiap-tiap variabel pembangun klaster daerah rawan dbd di DKI Jakarta. Analisis deskriptif dapat memberikan bayangan mengenai analisis lanjutan yang dapat digunakan selanjutnya. 


\section{Analisis Klaster}

Analisis klaster merupakan metode untuk mengelompokkan objek ke dalam klaster dimana objek-objek di dalam kelompok relatif homogen satu sama lain sedangkan antarkelompok bersifat heterogen. Perangkat lunak yang digunakan untuk menganalisis adalah R Studio versi 4.0.3. Berikut ini merupakan langkah-langkah dalam melakukan proses analisis klaster: (9), (10):

1. Merumuskan masalah, hal yang paling penting di dalam analisis klaster adalah pemilihan variabel-variabel yang akan dipergunakan.

2. Memilih ukuran kedekatan. Pada analisis klaster terdapat tiga ukuran kedekatan untuk mengukur kesamaan jarak antara pasangan obyek, jarak Euclidean, Squared Euclidean, dan Cityblock atau Manhattan.

3. Memilih prosedur proses analisis klaster, Terdapat dua metode umum dalam algoritma klaster, yaitu hierarki dan non-hierarki. Analisis klaster dengan metode hierarki ada beberapa metode yaitu metode pautan tunggal (single linkage), metode pautan lengkap (complete linkage), metode pautan rata-rata (average linkage), dan metode Ward (Ward's method). Pada metode nonhierarki terdapat metode K-means.

4. Menentukan banyaknya klaster, Menurut Sudjana (11), isi utama dalam analisis klaster adalah menentukan berapa banyaknya klaster. Sebenarnya tidak ada aturan yang baku menentukan berapa banyaknya jumlah klaster, namun demikian ada beberapa petunjuk yang bisa dipergunakan yaitu:

1. Pertimbangan teoritis, konseptual, praktis, mungkin dapat diusulkan untuk menentukan berapa banyaknya klaster yang sebenarnya.

2. Di dalam pengelompokkan hierarki, jarak dimana klaster digabung dapat digunakan sebagai kriteria.

3. Penentuan banyaknya klaster memperhatikan aspek kegunaan.

4. Menginterpretasi hasil klaster, Menurut Simamora (12), interpretasi dibutuhkan untuk memberi nama spesifik yang dapat menggambarkan isi klaster dan untuk mengetahui profil dari setiap klaster yang dibentuk dari rata-rata setiap klaster pada setiap obyek.

\section{Hierarchical Clustering}

Pada penelitian ini digunakan metode hirarki (bierarchical clustering), yaitu suatu metode pengelompokan data yang dimulai dengan mengelompokkan dua atau lebih objek yang memiliki kesamaan paling dekat, kemudian paling dekat kedua dan seterusnya sehingga klaster akan membentuk semacam pohon dimana terdapat hierarki (tingkatan) yang jelas antar objek, dari yang paling mirip sampai paling tidak mirip. Hasil dari metode hierarki dapat disajikan dalam bentuk dendogram. Dendogram adalah representatif visual dari langkah-langkah dalam analisis klaster yang menunjukkan bagaimana klaster terbentuk dan nilai koefisien jarak pada setiap langkah.

\section{Jarak Euclidean}

Dalam pengelompokannya digunakan suatu ukuran yang dapat menerangkan keserupaan atau kedekatan antar data untuk menerangkan struktur grup sederhana dari data yang kompleks, yaitu ukuran jarak atau similaritas dan ukuran jarak yang sering digunakan adalah ukuran jarak Euclidean (13). Jarak Squared Euclidean antara kelompok objek ke-i dan kelompok objek ke-j dari p variabel didefinisikan sebagai berikut:

Di mana:

$$
d i j=\sum_{k=1}^{p}\left(X_{i k}-X_{j k}\right)^{2}
$$

$\mathrm{P}=$ banyaknya variabel

dij $=$ jarak antara objek ke-i dan objek ke-j

$\mathrm{X}_{\mathrm{ik}}=$ data dari objek ke-i pada variabel ke-k

$\mathrm{X}_{\mathrm{jk}}=$ data dari objek ke-j pada variabel ke-k 


\section{Analisis Klaster Metode Ward's}

Untuk mengelompokkan kecamatan berdasarkan tingkat kerawanan DBD di Provinsi DKI Jakarta, dipilih analisis klaster metode ragam minimum (minimum variance atau ward's method). Metode ward's bertujuan untuk memperoleh klaster yang memiliki varian dalam klaster sekecil mungkin. Metode ini mengelompokkan objek berdasarkan pada kenaikan sum of square error (SSE). Pada tiap tahap, dua klaster yang memiliki kenaikan SSE paling kecil digabungkan. Formula untuk SSE adalah sebagai berikut:

$$
S S E=\sum_{j=1}^{N}\left(x_{j}-\bar{x}\right)^{\prime}\left(x_{j}-\bar{x}\right)
$$

Keterangan :

$x_{j}=$ nilai atau data dari objek ke-j

$\bar{x}=$ rata-rata dari keseluruhan objek dalam klaster

\section{Hasil dan Pembahasan}

DKI Jakarta memiliki luas wilayah sebesar 661,5kilometer persegi dengan jumlah penduduk pada 2016 sebesar 10,28 juta jiwa. Dengan wilayah yang yang tidak terlalu luas jika dibandingkan Provinsi lain dan jumlah penduduk yang banyak menjadikan DKI Jakarta provinsi dengan kepadatan penduduk tertinggi di Indonesia. Hal ini bisa membahayakan, mengingat salah satu penyebab perluasan demam berdarah adalah kepadatan penduduk (7).

Tabel 2

Rata-rata Variabel Berdasarkan Kabupaten/Kotamadya Tahun 2016

\begin{tabular}{|c|c|c|c|c|c|c|}
\hline $\begin{array}{l}\text { Nama Kota/ } \\
\text { Kabupaten }\end{array}$ & $\begin{array}{lr}\text { Luas Ruang } \\
\text { Terbuka Hijau } \\
\text { (meter persegi) }\end{array}$ & $\begin{array}{l}\text { Luas Tempat } \\
\text { Pembuangan } \\
\text { Sampah } \\
\text { (meterpersegi) }\end{array}$ & $\begin{array}{l}\text { Kasus } \\
\text { DBD }\end{array}$ & $\begin{array}{l}\text { RW } \\
\text { Rawan } \\
\text { Banjir }\end{array}$ & $\begin{array}{l}\text { luas wilayah } \\
\text { (kilometer } \\
\text { persegi) }\end{array}$ & $\begin{array}{l}\text { Jumlah } \\
\text { penduduk }\end{array}$ \\
\hline Jakarta Barat & 374040.1 & 2609 & 34.87 & 10.37 & 16.15 & 303801.2 \\
\hline Jakarta Pusat & 438521.9 & 1225.87 & 14.62 & 4.75 & 6.01 & 113798.9 \\
\hline Jakarta Selatan & 398219.7 & 2354.7 & 42 & 8.3 & 14.20 & 216370.8 \\
\hline Jakarta Timur & 359040.2 & 1560 & 43.1 & 16.8 & 18.83 & 281799.4 \\
\hline Jakarta Utara & 336023.5 & 1580.25 & 36.5 & 32.33 & 22.92 & 288240.7 \\
\hline $\begin{array}{l}\text { Kepulauan } \\
\text { Seribu }\end{array}$ & 20247.5 & 0 & 0 & 0 & 4.35 & 11505.5 \\
\hline
\end{tabular}

Sumber : data.jakarta.go.id (diolah)

Tabel di atas menunjukkan rata-rata untuk masing-masing variabel di kabupaten/kota di DKI Jakarta. Rata-rata variabel luas ruang terbuka hijau paling tinggi di Jakarta Pusat, dengan rata-rata luas ruang terbuka hijau 438521,9 meter persegi sedangkan paling kecil ada kabupaten Kepulauan Seribu . Rata-rata luas tempat pembuangan sampah paling tinggi berada di Jakarta Barat dengan rata-rata luas per kecamatannya sebesar 2609 meter persegi dan paling kecil di Kabupaten Kepulauan Seribu. Kasus DBD tertinggi berada di Jakarta Timur, dengan rata-rata jumlah kasus per kecamatannya sebesar 43-44 kasus. Sedangkan untuk jumlah RW rawan banjir, rata-rata paling tinggi berada di Jakarta utara, yaitu sekitar 3233 rw. Untuk rata-rata luas wllayah yang terluas ada di Jakarta Timur, sedangkan kab/kota dengan penduduk terbanyak ada di Jakarta Barat. Variabel-variabel tersebut akan digunakan untuk analisis klaster daerah rawan deman berdarah dengue. 


\section{Kasus DBD}

Angka Kasus DBD menunjukan berapa banyak kasus Demam Berdarah Dengue yang terjadi. Gambar peta tematik (Gambar 1) dan Grafik jumlah kasus DBD (Gambar 2) di bawah menggambarkan jumlah kasus DBD yang terjadi di Provinsi DKI Jakarta menurut kecamatan. Secara umum, hampir seluruh kecamatan memiliki jumlah kasus DBD kecuali kecamatan Kep. Seribu Utara dan Kep. Seribu Selatan.

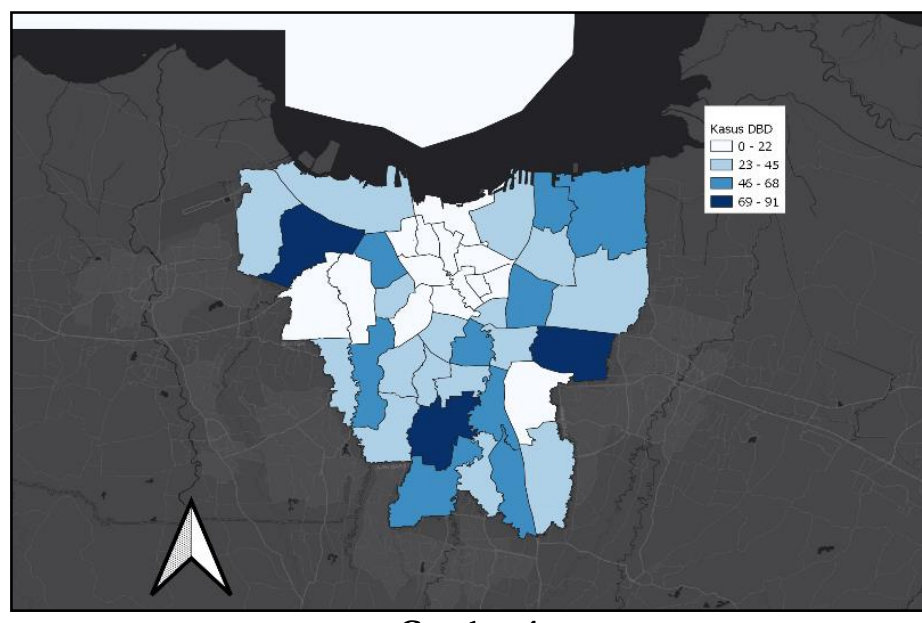

Gambar 1

Peta Sebaran Kasus DBD di DKI Jakarta Tahun 2016

Sumber: diolah

Gambar peta tematik di atas menunjukan persebaran kasus DBD di DKI Jakarta. Peta tematik menunjukan ada tiga kecamatan yang memiliki kasus lebih dari 69 kasus. Ketiga kecamatan tersebut berada di Jakarta Barat, Jakarta Selatan, dan Jakarta Timur masing-masing. Daerah dengan jumlah kasus kurang dari 22 kasus kebanyakan berada di Jakarta Pusat dan Kepulauan Seribu. Hampir seluruh kecamatan di Jakarta Pusat dan Kep. Seribu memiliki kasus kurang dari 22 kasus.

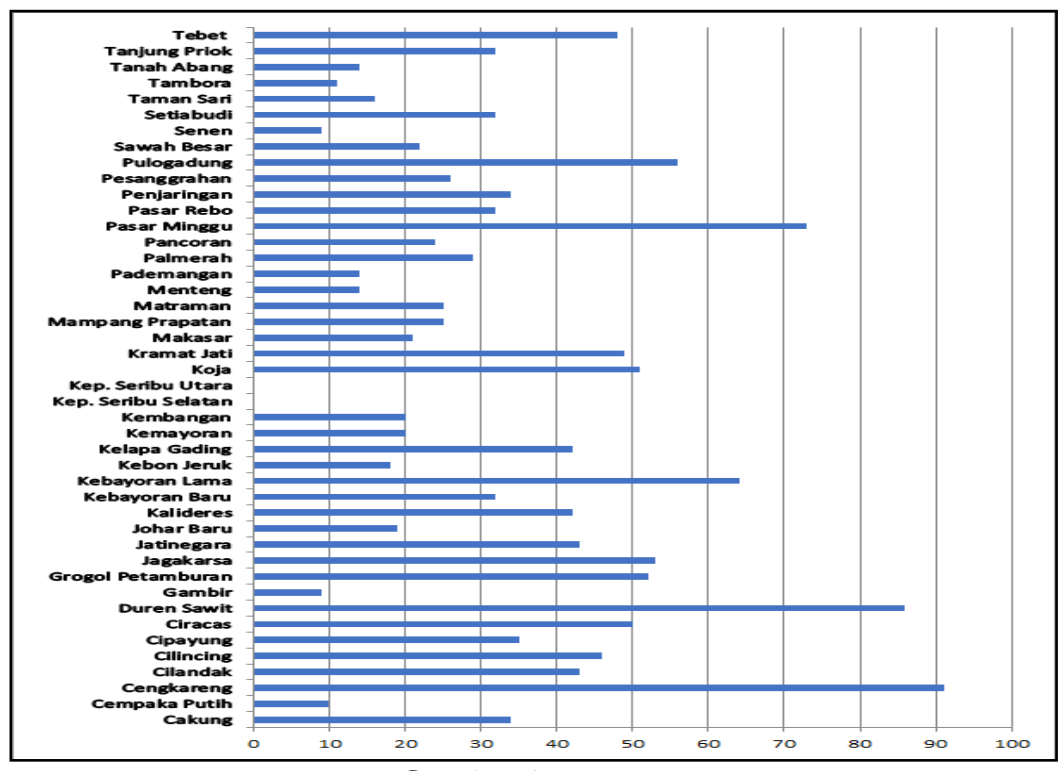

Gambar 2

Grafik Jumlah Kasus DBD di DKI Jakarta Tahun 2016 Sumber: Diolah 
Grafik di atas menunjukan gambaran jumlah kasus DBD di DKI Jakarta menurut kecamatan pada tahun 2016. Berdasarkan grafik, kecamatan yang memiliki jumlah kasus terbanyak adalah kecamatan Cengkareng, dan yang terbanyak kedua adalah kecamatan Duren Sawit. Kecamatan dengan jumlah kasus DBD terendah adalah kecamatan Kep. Seribu Utara dan Kep. Seribu Selatan, yaitu tanpa kasus DBD.

\section{Analisis Klaster}

Proses analisis klaster dari setiap kecamatan secara singkat dapat dilihat berdasarkan dendogram. Dendogram digunakan untuk menunjukkan anggota kelompok jika akan ditentukan berapa jumlah klaster yang akan dibentuk. Pada penelitian ini jumlah klaster yang akan dibentuk berjumlah tiga.

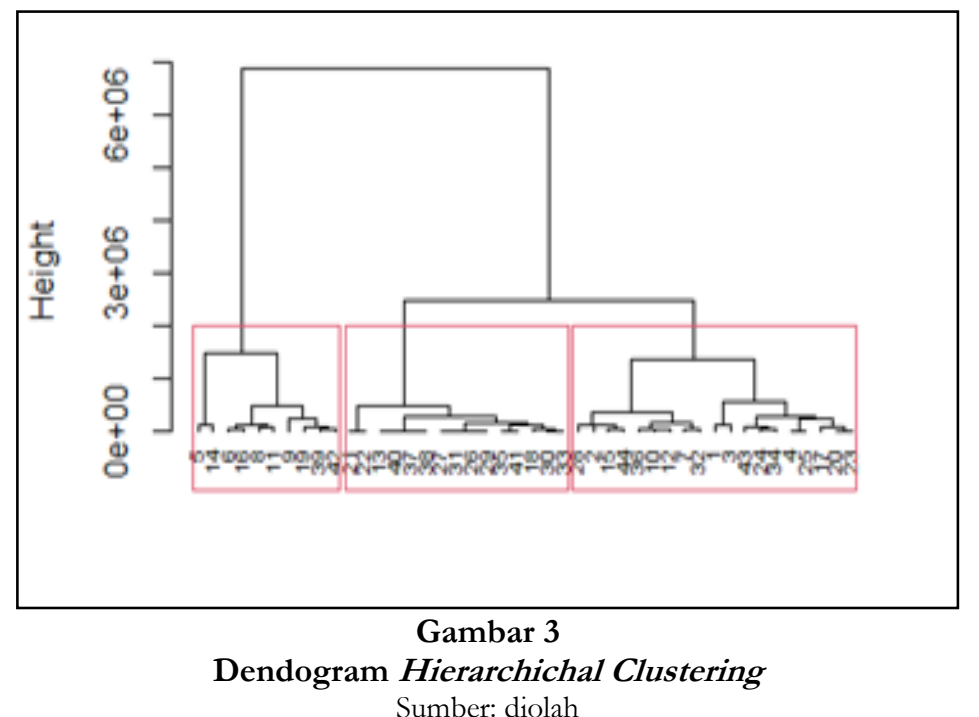

Klaster pertama, ditunjukkan oleh kotak paling kanan, adalah klaster yang berisi kecamatan dengan tingkat rawan DBD tinggi. Klaster kedua, ditunjukkan oleh kotak paling kiri, berisi kecamatan yang tergolong pada tingkat rawan DBD sedang. Sedangkan klaster yang ketiga, yaitu yang ditunjukkan oleh kotak yang berada di tengah, berisikan kecamatan dengan tingkat rawan DBD yang rendah.

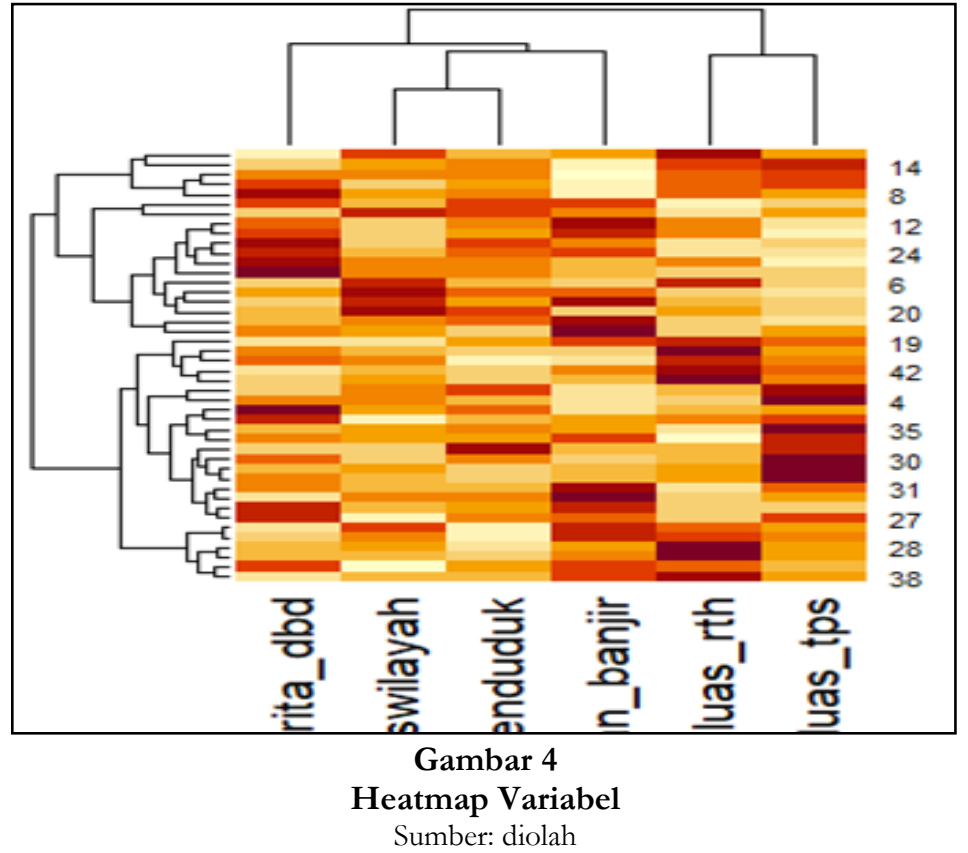


Selanjutnya terdapat beatmap untuk masing-masing variabel klaster. Heatmap tersebut menunjukkan semakin banyak warna gelap pada setiap variabel, maka semakin tinggi tingkat kerawanan DBD pada suatu kecamatan. Seperti pada heatmap kecamatan nomor 36 yaitu Pulogadung, memiliki warna merah bata di variabel jumlah kasus DBD, warna jingga dan jingga yang lebih gelap pada luas wilayah,jumlah penduduk dan luas ruang terbuka hijau, dan warna krem pada luas tempat pembuangan sampah, kemudian Pulogadung masuk dalam klaster 1 karena memiliki warna gelap yang lebih banyak.

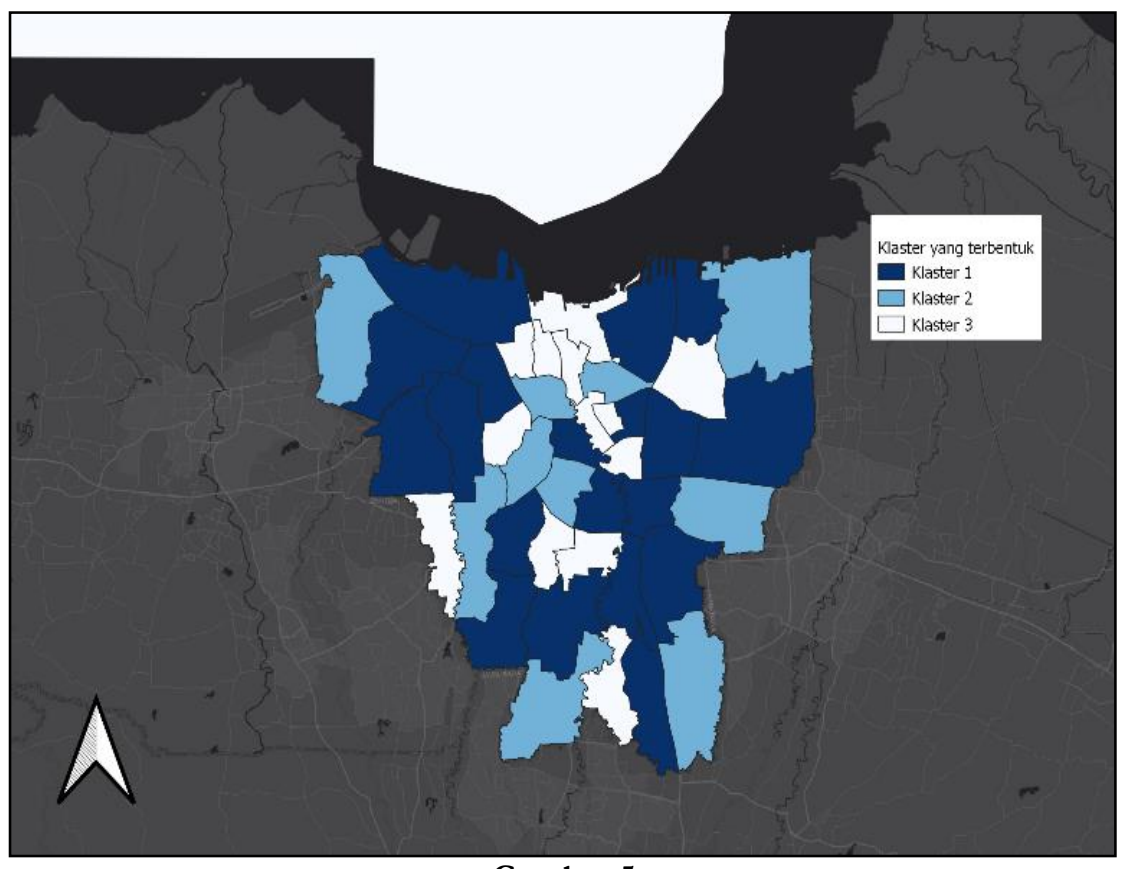

Gambar 5

Peta Persebaran Klaster Daerah Rawan DBD yang terbentuk Sumber : Dinas Kesehatan (diolah)

Berdasarkan peta persebaran tingkat kerawanan DBD di atas, dapat dilihat klaster kecamatan di Provinsi DKI Jakarta. Klaster yang mendominasi provinsi DKI Jakarta adalah klaster 1 yaitu tingkat kerawanan DBD tinggi dengan 19 kecamatan. klaster 1 terdiri atas kecamatan Cakung, Cempaka Putih, Cengkareng, Cilandak, Ciracas, Grogol Petamburan, Jatinegara, Kebayoran Baru, Kebon Jeruk, Kembangan, Koja, Kramat Jati, Makasar, Menteng, Pasar Minggu, Penjaringan, Pulogadung, Tanjung Priok, dan Tebet. klaster 2 yaitu tingkat kerawanan DBD sedang terdiri atas kecamatan Cilincing, Cipayung, Duren Sawit, Gambir, Jagakarsa, Kalideres, Kebayoran Lama, Kemayoran, Setiabudi, dan Tanah Abang. klaster 3 yaitu tingkat kerawanan DBD rendah berada di kecamatan Johar Baru, Kelapa Gading, Kepulauan Seribu Selatan, Kepulauan Seribu Utara, Mampang Prapatan, Matraman, Pademangan, Palmerah, Pancoran, Pasar Rebo, Pesanggrahan, Sawah Besar, Senen, Taman Sari, dan Tambora.

Dari peta tersebut, terlihat klaster 1 mengelompok di wilayah barat laut Jakarta yaitu Penjaringan, Cengkareng, Kembangan, Kebon Jeruk, dan Grogol Petamburan. Hal ini menandakan adanya kesamaan karakteristik kewilayahan pada daerah tersebut untuk mengelompok pada klaster 1. Pada gambar klaster 1 yakni tingkat kerawanan DBD tinggi paling banyak berada di Jakarta Timur. Hal ini sesuai dengan pernyataan Adrian tahun 2017 yang menyatakan Jakarta Timur merupakan daerah Endemik DBD. Dari peta tematik tersebut juga menunjukkan semua kecamatan di Kabupaten Kepulauan Seribu masuk dalam klaster 3 yaitu tingkat kerawanan DBD rendah. Hal ini menandakan Kabupaten Kepulauan Seribu masih aman dari kasus DBD berdasarkan variabel-variabel klaster. 


\section{Karakteristik Tiap Klaster}

Untuk melihat karakteeristik setiap klaster, digunakan diagram batang rata-rata variable tiap klaster. Dapat dilihat untuk rata-rata variable jumlah penduduk, luas wilayah, dan kasus DBD, klaster 1 dan klaster 2 memiliki rata-rata yang hampir sama. Untuk rata-rata variable luas ruang terbuka hijau dan luas tempat pembuangan sampah, klaster 2 memiliki rata-rata luas tertinggi. Sedangkan untuk rata-rata jumlah rw rawan banjir per kecamatan, klaster 1 memiliki rata-rata tertinggi secara berurutan diikuti klaster 2, lalu klaster 3. Dari semua variable, klaster tiga memiliki karakteristik rata-rata semua variable rendah. Klaster 2 memiliki karakteristik luas ruang terbuka hijau dan tempat pembuangan sampah tinggi, dan Klaster 1 memiliki karakteristik rata-rata jumlah rw rawan banjir tinggi.

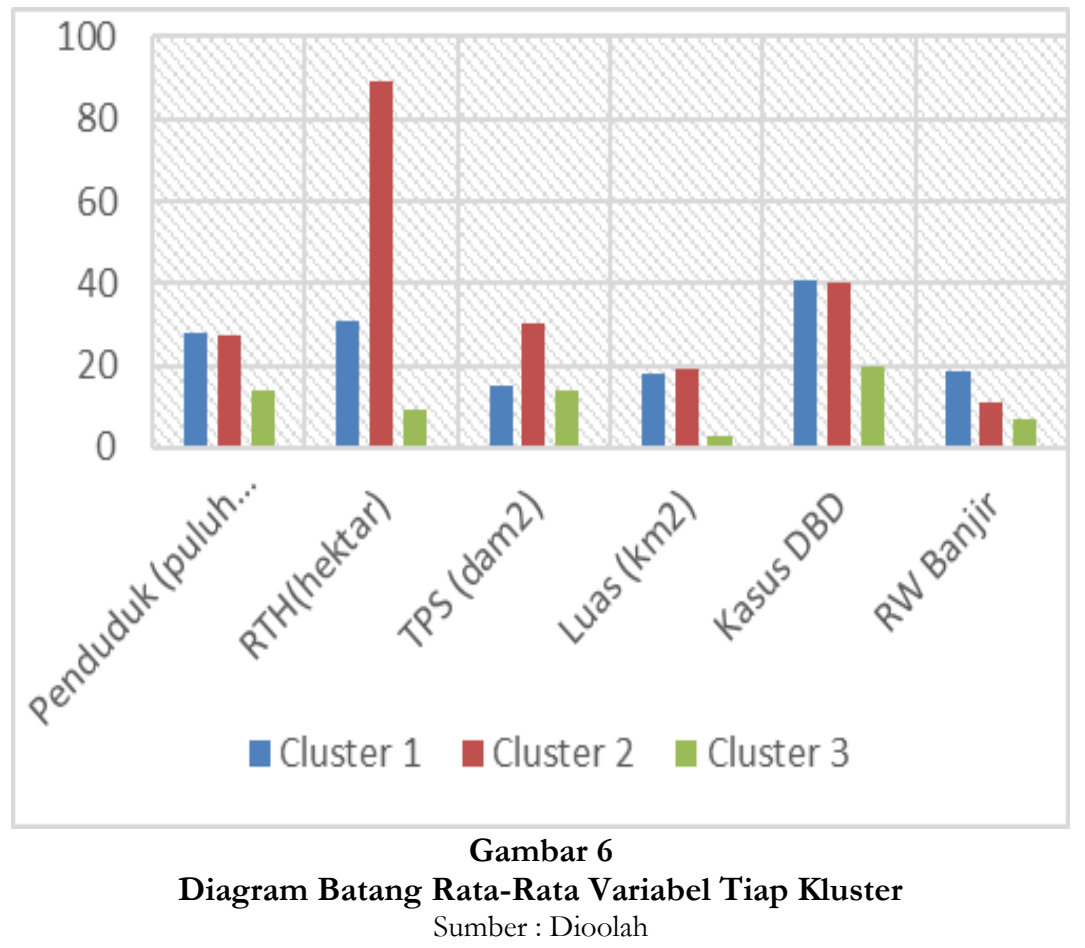

\section{Kesimpulan}

Secara umum diketahui bahwa kasus DBD paling banyak berada di Jakarta Timur. Akan tetapi, kecamatan dengan kasus DBD tertinggi berada di kecamatan Cengkareng. Selain itu, diketahui bahwa Kepulauan Seribu tidak memiliki kasus DBD di bulan Februari tahun 2016 pada saat data dikumpulkan. Kabupaten Kepulauan Seribu selalu memiliki statistik rata-rata paling rendah untuk setiap variabel pembangun klaster. Dari hasil pengelompokan dilakukan pengkategorian daerah menjadi tiga kategori. Kategori daerah yang dihasilkan yaitu, daerah dengan kerawanan tinggi, daerah dengan kerawanan sedang dan daerah dengan kerawanan rendah. Terdapat 19 kecamatan dengan tingkat kerawanan tinggi, 10 daerah dengan tingkat kerawanan sedang, dan 15 kecamatan dengan tingkat kerawanan rendah di Provinsi DKI Jakarta. Daerah dengan tingkat kerawanan DBD tinggi (klaster 1) paling banyak berada di Jakarta Timur. Untuk karakteristik per variabelnya, klaster tiga memiliki karakteristik rata-rata semua variable rendah. klaster 2 memiliki karakteristik luas ruang terbuka hijau dan tempat pembuangan sampah tinggi, dan klaster 1 memiliki karakteristik rata-rata jumlah rw rawan banjir tinggi. Dengan mengetahui hasil dari pengelompokan, diharapkan dapat mempermudah dalam melakukan tindakan dalam hal penanganan maupun pencegahan demam berdarah dengue di DKI Jakarta baik bagi pemerintah maupun masyarakat. Bagi pemerintah, dengan mengetahui kecamatan mana yang masuk kategori dengan kerawanan tinggi dan sedang, dapat memberikan perhatian lebih dan dapat menentukan kebijakan lebih tepat lagi kedepannya. Untuk masyarakat, dapat lebih berhati-hati jika sedang menempati suatu daerah, berniat menempati suatu daerah, atau bepergian ke daerah-daerah dengan tingkat kerawanan tinggi atau sedang, tanpa persiapan khusus. 


\section{Daftar Pustaka}

1. Soedarto. Demam berdarah Dengue : Dengue Haemorrhagic Fever. Jakarta: Sagung Seto; 2012.

2. Dinas Kesehatan DKI Jakarta. Profil Kesehatan DKI Jakarta. 2016.

3. Nareza M. Daerah Berisiko Tinggi DBD [Internet]. 2021 [cited 2021 May 27]. Available from: https://www.alodokter.com/daerah-berisiko-tinggi-DBD

4. Ramadhani A, Widayani P, Widartono BS. Pemetaan kerawanan penyakit demam berdarah Dengue Menggunakan Metode Multi Kriteria di Kecamatan Purwokerto Timur. J Bumi Indones [Internet]. 2014;3(2):1-9. Available from: http://lib.geo.ugm.ac.id/ojs/index.php/jbi/article/view/625

5. Harsoyo B. Mengulas Penyebab Banjir Di Wilayah Dki Jakarta. J Sains Teknol Modif Cuaca. 2013;14(1):37-43.

6. Tarmana D. Potensi Peluang Demam Berdarah Dengue Berdasarkan Proyeksi Perubahan Iklim ( Study Kasus : DKI Jakarta). Indones J Infect Dis. 2013;1(2):14-22.

7. Achmadi UF, Sukowati S. Demam Berdarah Dengue. Bul Jendela Epidemiol. 2010;2.

8. Ruliansyah A, Yuliasih Y, Hasbullah S. Pemanfaatan citra ASTER dalam penentuan dan verifikasi daerah rawan Demam Berdarah Dengue (DBD) di Kota Banjar Provinsi Jawa Barat. ASPIRATOR - J Vector-borne Dis Stud. 2015;6(2):55-62.

9. Supranto J. Analisis Multivariat Arti dan Interpretasi. Jakarta: Rineka Cipta; 2004.

10. Pramana S, Yuniarto B, Mariyah S, Santoso I, Nooraeni R. Data Mining dengan R Konsep Serta Implementasi. Jakarta: In Media; 2018.

11. Sudjana. Metode statistika. Bandung: Tarsito; 2002.

12. Simamora B. Analisis Multivariat Pemasaran. Gramedia Pustaka Utama; 2005.

13. Johnson RA, Wichern DW. Applied Multivariate Statistical Analysis. 6th ed. New Jersey: Prentice Hal, Inc.; 2012. 